\title{
Aorto-iliac Steal Syndrome
}

1966年 Kountz らは，大動脈一腸骨動脈閉塞 例の血行再建術後に腸管間膜動脈閉塞をおこし 死亡した 1 例を報告し，血流が再建された末梢 血管領域に再分配されたために腸管の阻血を拉 こしたと考劣，これを aorto-iliac steal とよん だ. それまでにも, 大動脈切除術後の腸管壊死 の報告は多くみられたが，下腸間膜動脈の切断 が原因と考えられていた。腹腔動脈や上腸間膜 動脈に狭窄のある例では, 下腸間膜動脈が主と して腸管への血行を支配し，これを切断するこ とによって腸管の阻血が増悪するとされたわけ である。しかし腸管の壊死は，下腸間膜動脈の 切断を行なわない bypass graft や血栓内膜摘 除術後にもおこることが知られており，これに は腸間膜動脈の術後血栓閉塞が重要と考兄られ た. Kountz らは, 上腸間膜動脈血流が, 再建さ れた末梢血流にうばわれる，いわゆる borrowing-lending 現象のために腸間膜動脈内に血栓が 生ずると考えた. 彼らは犬を使って実験的に, 大 動脈一腸骨動脈狭窄を作り，それを解除すると 上腸間膜動脈の血流が減少することをみた。さ らに腰部交感神経節切除を行ならと, ょり多く の血流が末梢に再分配されると報告している.

閉塞性動脈硬化症では, 長い期間に腹腔動脈 や上腸間膜動脈狭窄を括こすことがあるが，大 部分は腸管への側副血行が発達し, 腸管の阻血 症状は出現しない。しかしこの場合, 血流は限 界状態に近いことが多く，このようなとき，血 行再建によって腸管血流が末梢血流に再分配さ れると腸管の阻血症状が出現するわけである.

Kountz らの 報告以後, 1967 年に Lancaster らが，1968年に William らが，ついで1972年 に Trippel らが おの拈の 1 例づつ同様の症例
を報告し，現在まで 4 例をかぞえる。

全例大動脈一腸骨動脈に閉塞があって，1 側 または両側下肢に阻血症状を有しており，その ため, 3 例に両側の aorto-iliac または aorto-femoral bypass 手術を, 他の 1 例には 1 側の bypass 手術を行なった. その結果, 患肢の症状改善 をみたが，いずれも術後腸管壊死を拈こして死 亡した，腸管の壊死症状は, 全例とも術後比較 的早期に出現したが，診断は剖検時あるいは腸 管の血行再建が不能な遅い時期にやっと確定し ている。剖検所見では，小腸全体に硬塞を認 め, 上腸間膜動脈は血栓により閉塞していた.

aorto-iliac steal をおこして死亡する例は比 較的まれで, Trippel らは60例の aorto-femoral または aorto-iliac bypass 術後, わずか 1 例に のみ認めている。 bypass 形成によって下肢の 血流が増加すると, 腸管の血流量は多かれ少な かれ減少するが，術前腸管血流に障害のないも のでは，阻血症状を拈こすには至らない．

前述の 4 例は, 全例とも血行再建術を行なう 前に動脈撮影が施行されて扣り, 腸管の血行状 態は予想されていた。 3 例には大きな側副路あ るいは上腸間膜動脈の meandering がみられ, 上腸間膜動脈狭窄がうたがわれて敃り，1例で は上腸間膜動脈狭窄々のものが認められてい た. 術前に intestinal angina をらたがわせる 症状を有したのは 1 例のみで, 他の 1 例では腸 管血行不全症状はなかったが，前述のごとく血 管撮影で腸管血行障害の存在が考兄られていた わけである。

3 例は両側 graft 手術のみで交感神 経節切 除は行なっていない. したがって, 交感神経節 切除は腸管壊死の発生に絶対的条件ではないと 
考えられる。

血行再建手術後の aorto-iliac steal による上 腸間膜動脈閉塞を予防するためには，第一に術 前に血管撮影を行ない腸管血行不全の有無を予 知することが大切である. abdominal angina が 存在すればもちろん，なくても血管撮影で上腸 間膜動脈狭窄叔よび meandering arteryを認め れば，腸管血行障害をらたがうべきで，時には これらの血行再建をも考兄る。術中には上腸間 膜動脈にとくに注意をはらいthrill の存在をし らべる。 大さな側副路があったら腸管血行障 害を考光，この側副路はでさるだけ温存するよ らこころがける。 aortic clamp の使用中は, 狭 窄した上，下腸間膜動脈内血栓形成を予防する ために, ヘパリンを使用したり，遮断時間を最 少限にとどめる. graft 縫合時には，側副路の でていることの多い下腸間膜動脈起始部はでき るだけのこすようにする. clamp 解除時は血圧 低下を沶こさぬようにする。手術終了前には, 再度上, 下腸間膜動脈拍動を確認する，などの 注意が大切である。

手術直後に腸管阻血の診断を確定することは 困難なことが多い．したがって，常にこの可能 性を考慮し，できるだけ対処するように努める べきであると考える。

DeBakey は大動脈一腸骨動脈閉塞の血行再建
術を行なら前に，頸動脈の血流をしらべ，血行 障害をらたがわれる場合は, 頸動脈の血行再建 をまず行なうべきであると述べている. Kountz はこの臨床的考察に同意し，大動脈一腸骨動脈 閉塞再建後の血行再分配は頸動脈にも括こると 説明している，この頸動脈系の血流の下肢への steal は, 自律神経調整による反射的頸動脈収 縮によって扣こるとされ, 内頸動脈狭窄のある 患者ではこの steal のために, 脳血行不全を拉 こすと考えられている. この steal 現象は, こ の他にも全身のあらゆる血管に拈こると考学ら れる。

腸間膜動脈の場合も血管反射性収縮による血 流減少も考光られ，Kountz らは実験的に上腸 間膜動脈の neurectomy が急性腸間膜動脈閉塞 の予防括よび治療に有効であると述べている。 彼は腸管血行障害の考兄られる症例に下肢への 血行再建術を行なら場合には, 上腸間膜動脈 の neurectomy を併用することを推奖してい る.

これまで aorto-iliac steal による腸管壊死の 発生頻度は比較的少ないが, 今後血行再建の適 応例が増加するにつれて，ますます問題となる 機会が多くなる可能性がある。

（東京大学・第一外科 大橋 重信）

月刊臨床雑誌 